\title{
Climate factors influencing effective use of geothermal resources in SE Poland: the Lublin trough
}

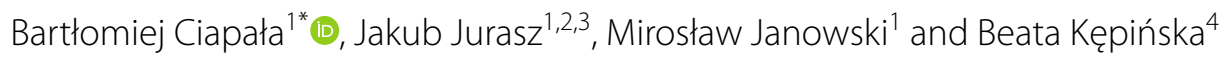

\author{
*Correspondence: \\ bciapala@agh.edu.pl \\ ${ }^{1}$ AGH University of Science \\ and Technology, Kraków, \\ Poland \\ Full list of author information \\ is available at the end of the \\ article
}

\begin{abstract}
Although geothermal resources are practically independent of climate factors, those factors significantly condition the potential use of the Earth's natural heat resources. Unlike all the other factors limiting or facilitating the use of geothermal heat (like receivers' temperature expectation, financial issues or local regulations), climate factors remain immovable. Thus, climate remains the main factor influencing the effective use of geothermal resources. Volumes of sold energy, typical capacity factors and rapid changes in heat demand may all influence the financial and technological performance of an investment. In the current paper, climate factors are translated into heat demand based on historical data (meteorological and district heating logs) by means of a dedicated artificial neural network, and analysed in terms of possible constraints and facilitators that might affect the effective use of geothermal energy. The results of ANN simulation indicate that average and typical operation is expected without any turbulences, yet about $10 \%$ of operating hours may require additional technical measures, like peak source support, smart management and buffers in order to limit pumping ramp rate. With appropriate dimensioning and exploitation, capacity factors as high as $60 \%$ are available, proving the potential for financially and environmentally effective use of geothermal resources.
\end{abstract}

Keywords: Geothermal resources, Climate, Weather, Peak source

\section{Introduction}

Geothermal energy is suited to providing heat as a base source, both in rural and urban areas, using local and sustainable heat. Yet, the investment costs are significantly higher than conventional heat sources, especially because of costs and risks related to drilling (without geological risk insurance). Thus, it is crucial to properly assess the challenges and opportunities not only of geological build-up but also of surface circumstances. Development-driven conditions, like number and size of potential heat receivers, and climate-driven conditions, like duration of heating season and amount of energy sold per dwelling, are of the highest importance when decisions are made (Lund and Lienau 2009). Detailed computations, like those proposed by Lund and Lienau, that include climatological data are usually performed for specific locations.

(C) The Author(s) 2021, corrected publication 2021. Open Access This article is licensed under a Creative Commons Attribution 4.0 International License, which permits use, sharing, adaptation, distribution and reproduction in any medium or format, as long as you give appropriate credit to the original author(s) and the source, provide a link to the Creative Commons licence, and indicate if changes were made. The images or other third party material in this article are included in the article's Creative Commons licence, unless indicated otherwise in a credit line to the material. If material is not included in the article's Creative Commons licence and your intended use is not permitted by statutory regulation or exceeds the permitted use, you will need to obtain permission directly from the copyright holder. To view a copy of this licence, visit http://creativecommons.org/licenses/by/4.0/. 
The influence of climate and climate change on renewable energy sources and, in general, on energy systems' productivity and accessibility is undisputable and well recognised in the literature (Canales et al. 2020; Tobin et al. 2016; Kozarcanin et al. 2017). Comparatively high outdoor temperatures not only affect the effectiveness of power systems but also directly influence shallow geothermal (Tissen et al. 2018; Schüppler et al. 1995) systems as well as district heating systems (Gustafsson 1992). These include geothermal district heating systems (geoDH). These are affected by climate conditions not in terms of source abundance or accessibility, but rather in terms of sold energy amount and required output changes and guaranteed capacity (which are obligatory for any kind of district heating), which are also crucial in innovative concepts (Matuszewska et al. 2020). GeoDHs are environmentally friendly and well suited to urban areas as they are perceived to be mostly non-negative (Vargas 2018; Kunze and Hertel 2017; Pellizzone et al. 2020) yet vulnerable in terms of short-term stability of exploitation. Still, exploitation of geothermal heat resources remains one of the most promising renewable heat sources available in a significant share of populated areas.

In general, climate may influence a geothermal facility in several ways. The first and most obvious one is amount of energy sold. The second is related to peak heat demand, which is the maximal required heat capacity in a geothermal plant. These two contribute to capacity factor (CF), which is crucial to the economic effectiveness of the investment. In fact, high and rarely occurring values of peak heat demand are the reason why a non-geothermal peak heat source is used in geoDHs. This practice is common in low-temperature geothermal areas of Central Europe (Kępińska 2016; Weber et al. 2016). The last, important, yet poorly described and quantified climate factor is the influence of heat demand oscillations on exploitation, since geothermal wells are not suited to working with high ramp rates. The main reason for this is the reservoir's inertia and related risk of particles being mobilised when production volume is rapidly increased ( $\mathrm{Li}$ et al. 2017). Particle mobilisation may ultimately decrease permeability, as well as eroding the well casing and surface equipment and increasing their corrosion.

All the factors mentioned above are quantified and calculated with mathematical models. These models consist of various algorithms whose level of detail, as investor to vary from case to case. Also, it remains the investor's decision as to whether the expected share of peak source, level of uncertainty and risk are acceptable. Because of this, the present article does not evaluate parts of the considered region as suitable or unsuitable but, rather, focuses on the climate conditions that would influence the effective use of geothermal energy in the Lublin trough (Additional file 1). The trough itself is a geological structure (a syncline) in south-eastern Poland (Central Europe) that exhibits potential in the low-temperature geothermal resources expected in sedimentary (clastic and carbonate) rocks, especially in Jurassic reservoirs of moderate thickness. Such rocks may tend to release particles into the well, especially during changes in rapid pumping rate. This may lead to reservoir failure or damage, which may harm the investment, especially in cases of small reservoir thickness. Therefore, and because the resources are expected to be in a low temperature range (maximally $60{ }^{\circ} \mathrm{C}$ in the Lublin area at a depth of $2000 \mathrm{~m}$ with dominating lower temperatures in 
shallower reservoirs outside Lublin), there is a need to precisely evaluate the conditions in which a geothermal system might operate, in order to avoid low capacity factors and exploitation problems.

The aim of this article is to analyse the aforementioned ways in which climate influences a potential geoDH, on the example of the Lublin trough. Considerations are based on historical meteorological data, used along with heat demand information from a geoDH operating nearby. These are used together with an artificial neural network (ANN) to simulate geothermal district heating systems: ANNs are a recognised tool for simulating both geoDHs (Yabanova and Keçebaş 2013) and conventional DHs (Guelpa et al. 2019).

Although the performed calculations may be useful for a variety of heat sources, the analyses and discussion contained here focus on geothermal district heating systems for large-scale individual geothermal heat receivers, with temperature parameters adjusted to the available geothermal resources. This assumption may be realised by means of an ultra-low-temperature district heating system (ULTDH) ${ }^{1}$ employing heat pumps, or a low-temperature district heating system (LTDH). ${ }^{2}$ This direction in modifying heating systems is suggested both in EU-funded projects (TEMPerature Optimisation for Low Temperature District Heating across Europe, COOL DH) and in the literature (Østergaard and Svendsen 2017; Volkova et al. 2019). Although currently perceived in some places to be a conceptual novelty and to require excessive effort, limited requirements for heating temperature parameters are the future of district heating systems.

Specifically, the scientific novelty of this article is as follows:

- Regional assessment of climate conditions influencing the effective use of geothermal energy for heating purposes

- Use of artificial neural networks to simulate the operation of geothermal district heating

- Regional assessment of heat demand ramp rates expected to be observed, on the example of the Lublin trough (SE Poland)--a geological structure with potential for low-temperature geothermal exploitation

\section{Input data and methods}

The first step was to determine the boundaries of the study area. There are various definitions of the Lublin trough: some tectonic divisions of Poland split it into multiple units. The definition used by the authors follows the outline by Pożaryski (Pożaryski 1974). Once the area was strictly described by the vector file from the project, meteorological stations collecting interesting data were sought to provide reliable data on weather conditions over a long time period. The significant time period was assumed to be 15 years [1st Jan 2005 to 31th Dec 2019; elsewhere, for similar considerations, 10 years (Chicherin 2020)], as these years are properly covered by available meteorological stations and

\footnotetext{
${ }^{1}$ ULTDH is defined as district heating with temperature insufficient to prepare sanitary hot water, or, in other words, of supply temperature lower than $50^{\circ} \mathrm{C}$.

${ }^{2} \mathrm{LTDH}$ is defined as district heating with a supply temperature $50^{\circ} \mathrm{C}$ or $55^{\circ} \mathrm{C}$ and a return temperature $25^{\circ} \mathrm{C}$ lower.
} 


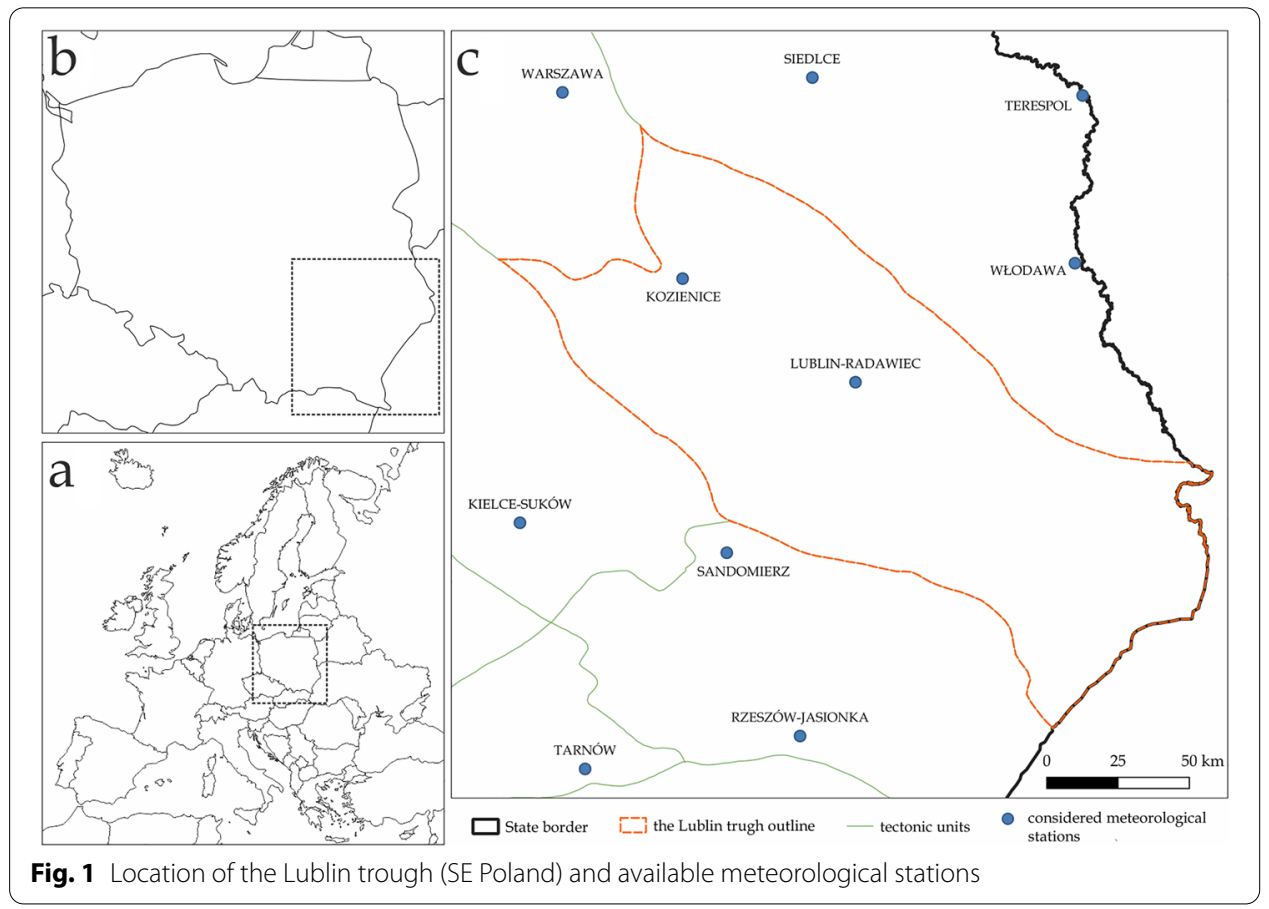

constitute the longest common log period for stations providing simultaneous availability of the required data in or around the Lublin trough. Also, because of climate change, older data may exhibit deviations compared to modern years (e.g. Chicherin 2020), which might cause model distortion. An outline of the study area and the location of useful meteorological stations are presented in Fig. 1.

Temperature and wind speed data were obtained from the Polish Institute of Meteorology and Water Management-National Research Institute database, whilst irradiation data were downloaded for exactly the same coordinates from the Copernicus Atmosphere Monitoring Service (CAMS) database. The time series was checked for validity and the few gaps were filled with respective hourly values from their closest temporal vicinity. The shortest gaps were filled with averaged values of respective measurements from the closest vicinity. The total number of gaps in all datasets (five parameters in hourly meteorological datasets over 15 years in 10 locations) was less than 2500 , which is less than $0.2 \%$ of all records. The number of selected meteorological stations was limited by data availability among all meteorological stations. Continuous series were encoded in a form useful in the next step.

The data and results for meteorological stations within the Lublin trough and in its surroundings were analysed statistically and for illustration were presented as maps (Figs. 2 and 3).

To assess climate factors influencing the effective use of geothermal resources in the Lublin trough, a dedicated artificial neural network (ANN) was deployed by the authors to simulate heat demand in the considered meteorological stations. ANN is a non-deterministic tool for modelling that provides results more varied than those obtained from a heating curve; thus, the results are congruent to actual heat demand fluctuations. The ANN was fed with input data provided by Geotermia Mazowiecka S.A., the geothermal 


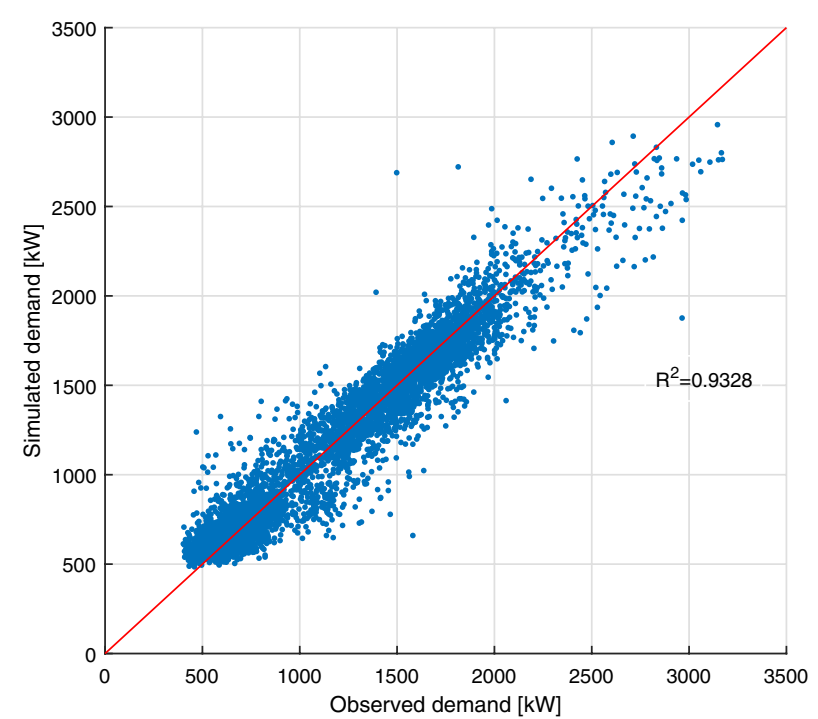

Fig. 2 Accuracy of ANN estimation: observed heat demand vs demand expected according to ANN results

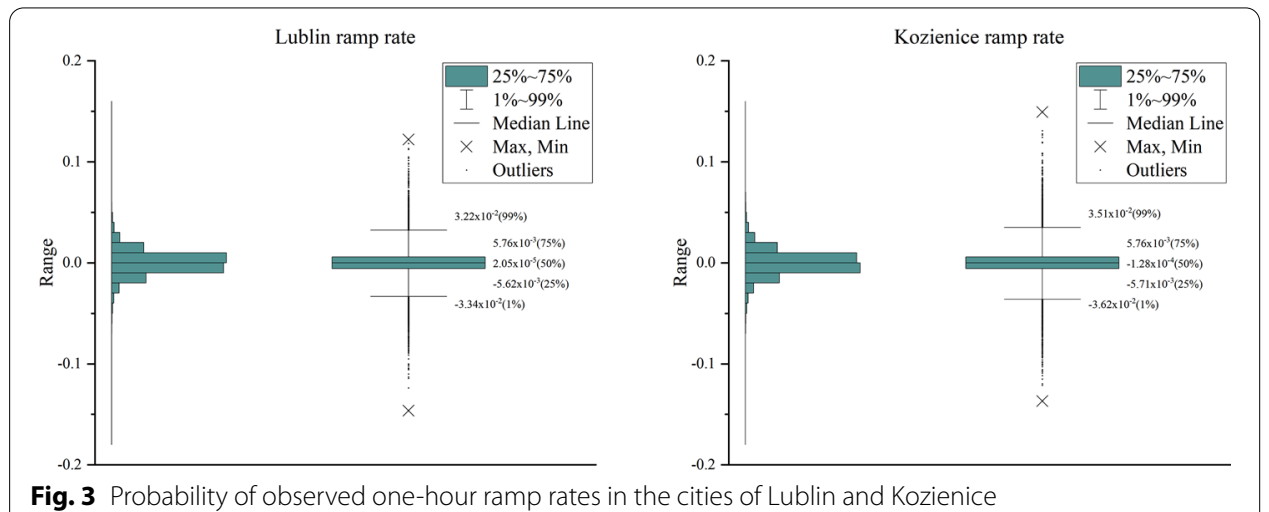

heating plant in Mszczonów, on the nearby northern boundary of the research area, which was considered to probably experience similar geothermal and climate conditions and to exhibit similar citizen habits. The abundant available datasets include time series of an entire representative district heating providing heat for various types of heat consumers-single-family houses, multi-family houses, swimming pools and commercial receivers were used. Datasets for the years 2014-18 regarding heat demand along with external temperature, solar irradiation and wind speed from the nearest meteorological station were used to train the ANN. The teaching population was chosen for the stability of observations and homogeneity.

In recent years, the use of machine learning techniques has gained immense popularity in engineering and scientific applications (Mosavi et al. 2019). The most commonly used tools include artificial neural networks (ANN), which attempt to map the structure and operation of the human brain (Beale et al. 1996). From the large variety of different types of ANNs, good performance is usually obtained with relatively low 
computational effort by using a standard multilayer perceptron (MLP). ANNs have also been widely applied in the area of heating systems, both for load prediction (Song et al. 2020) and for system control (Guelpa et al. 2019).

For the purpose of the analysis conducted in this work, an ANN was created in Matlab 2019a by applying the fitnet function. As input data, the authors considered a four-year, hourly time series of meteorological parameters (humidity, wind speed, air temperature and global horizontal irradiation, obtained from the Institute of Meteorology and Water Management-National Research Institute [IMWM-NRI]) and dummy variables in the form of the 'hour of the day' and 'month of the year'. In total the input consisted of 40 explanatory variables. As output, the authors used the hourly observed heat demand recorded in the town of Mszczonów. The data were normalised. For the purpose of creating the ANN, the data were divided randomly (Matlab dividerand) into teaching ( $70 \%$ of samples), validation (15\% of samples) and testing (15\% of samples) subsets. The Levenberg-Marquardt was selected as the teaching algorithm due to its fast convergence. As activation the sigmoid and linear functions were selected in the hidden and output layers, respectively. The number of neurons in the hidden layer is an issue for which there are many potential answers (Sheela and Deepa 2020). Considering the above, it was decided to test the performance of ANNs with the number of neurons in the hidden layer ranging from 1 to 20 , where the upper bound was established based on the rule proposed by Mukhopadhyay and Mukhopadhyay (Mukhopadhyay and Mukhopadhyay 2018). From the array of developed neural networks the one with the lowest mean absolute percentage error (MAPE) was selected. In this particular case, an ANN with 10 neurons in the hidden layer was selected, with an MAPE of 9.32\%. Its performance is presented in Fig. 4.

Once the ANN was ready, it processed previously prepared datasets for meteorological stations in or nearby the study area. The results were normalised. The nominal heat demand $\left(D^{\text {nominal }}=1.0\right)$ was set as $3200 \mathrm{~kW}$, which is a rounded-out value observed at $-20{ }^{\circ} \mathrm{C}$ and average for its immediate vicinity $\left( \pm 0.5^{\circ} \mathrm{C}\right)$. Nominal design external temperature for the entire Lublin trough is $-20^{\circ} \mathrm{C}$ according to Polish norm PN-EN 12,831, for which all heat loads in this region should be calculated. Such an approach has previously been presented and widely discussed for general evaluation of geothermal systems (Ciapała et al. 2019), and is also presented hereunder in Appendix 1. Normalised demand/production may also be found elsewhere (Kryzia et al. 2020).

Based on ANN results, ramp-up and ramp-down rates were calculated separately as Eq. 1 (Jurasz and Ciapała 2018):

$$
R=D_{(\mathrm{i}+1)}-D_{(\mathrm{i})}
$$

Since there is no clear technical limit of heat capacity covered by the geothermal source, for peak source dimensioning it was arbitrarily assumed that the first instance of a higher-than-median value for which the following equation is valid is the point at which the peak heat source should begin to operate (indexes for ordered time series). Thus, the maximal geothermal capacity is assessed according to Eq. 2 and the peak source size is set according to Eq. 3. Peak source covers only the part of demand 

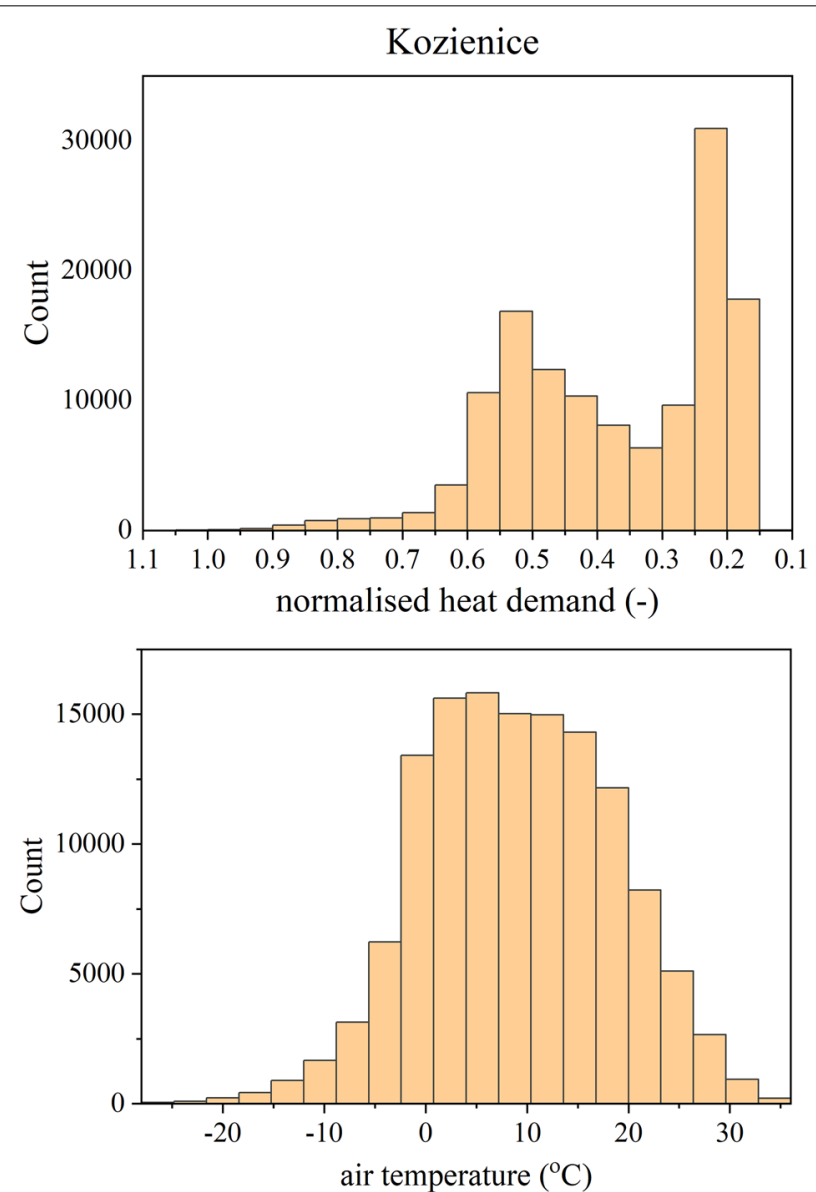

Fig. 4 Temperature (lower) and heat demand (upper) histograms. The bimodal histogram of heat demand results from there being two clearly distinct seasons: summer (with SHW preparation) and winter (SHW and space heating)

exceeding the capacity of the geothermal well. The value of $0,00,025$ within the equation was set arbitrarily based on load curves analyses:

$$
\begin{aligned}
& C_{\max }^{\text {geothermal }}=\max D_{(\mathrm{i})}: D_{(\mathrm{i})}+0,00025<D_{(\mathrm{i}+10)} \\
& C^{\text {peak }}=1-C_{\max }^{\text {geothermal }}
\end{aligned}
$$

This criterion selects points in the steepest part of the duration time graph representing values reached only in peaks, without similar values occurring in the neighbourhood. For values chosen in this procedure, capacity factors were calculated for the entire period of observation. The use of capacity factors for the assessment of partly loaded energy systems is known and accepted (Kies et al. 2016). Calculations followed Eq. 4, which is modified version known from elsewhere (Mines et al. 2015):

$$
\mathrm{CF}=\frac{\sum_{i=1}^{n} \min \left(P_{i} ; P_{\max }^{\text {geothermal }}\right)}{n \cdot P_{\max }^{\text {geothermal }}}
$$




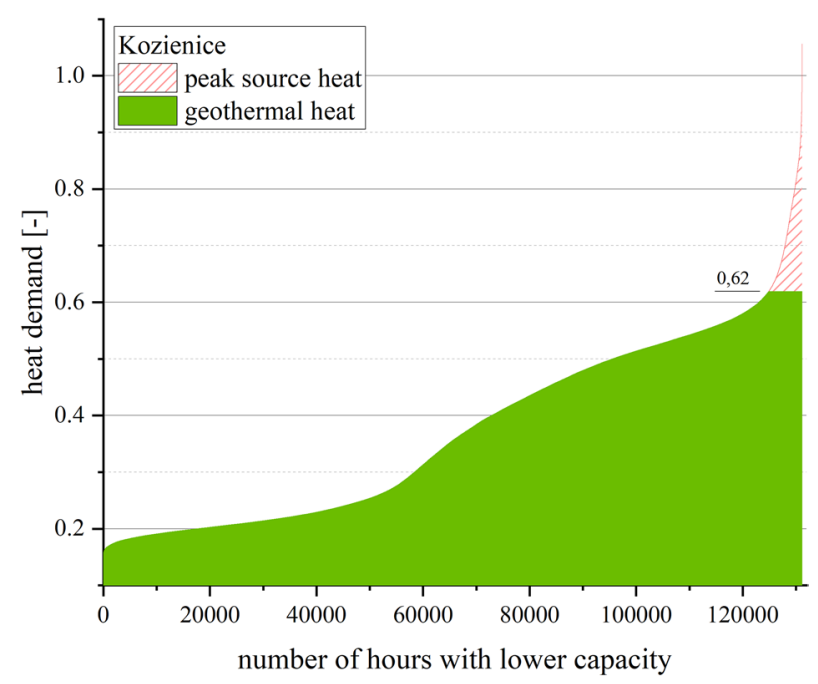

Fig. 5 Normalised heat demand duration curve. The filled areas represent demand covered by geothermal heat source (solid green) and peak heat source (dashed red). The cut-off value for geoDH peak source was assessed to be about $62 \%$ of nominal heat demand (according to Eq. 2 criterion)

\section{Results}

The ANN provided time series which were used for statistical analyses and comparisons presented below. Analyses included preparation of time series, load curves and extraction of statistical values (minimum, maximum, mean and median values, 1st, 25th, 50th, 75th and 99th percentiles) for load and hour-to-hour heat demand change. Results were visualised; both heat demand curves and heat demand changes were plotted in suitable graphs. This part of work was done in the Origin Lab software.

In general, bulk observations around the Lublin trough are similar, which is to be expected in light of the distances involved being less than $300 \mathrm{~km}$. There is an observable shift in peaks in observations made in time series. This leads to the conclusion that heat management might be improved.

According to the effects of the simulations, there is a $50 \%$ chance that ramp rate values are in the range of 0.006 to -0.006 and are higher to the north and east (a more continental climate). A nominal power of $1,000 \mathrm{~kW}_{\mathrm{t}}$ translates into smooth changes in heat demand-usually changing hour-to-hour by $6 \mathrm{~kW}_{\mathrm{t}}$. The median value is close to 0 , which is to be expected. There is $98 \%$ confidence that hour-to-hour heat demand change is in the range of -0.02 to 0.02 or $\pm 20 \mathrm{~kW}_{\mathrm{t}}$ per $1000 \mathrm{~kW}_{\mathrm{t}}$ of nominal power. Maximal observed ramp rates are -0.19 and +0.15 (or $-190 /+150 \mathrm{~kW}_{\mathrm{t}}$ per $1000 \mathrm{~kW}_{\mathrm{t}}$ ). Such values are clearly outliers, yet ramp rate values in ranges from +20 to $+150 \mathrm{~kW}_{\mathrm{t}}$ and -20 to $-190 \mathrm{~kW}_{\mathrm{t}}$ cannot be neglected for their $2 \%$ chance of occurrence. Box plots for Lublin and Kozienice (which is within the Lublin trough) are presented in Fig. 5.

Analysing the bulk results, the following observations can be made:

- Heat demand very rarely reaches nominal heat demand, let alone exceeding it. For Lublin, there is less than a $0.2 \%$ chance that $90 \%$ of nominal heat demand would be reached. 


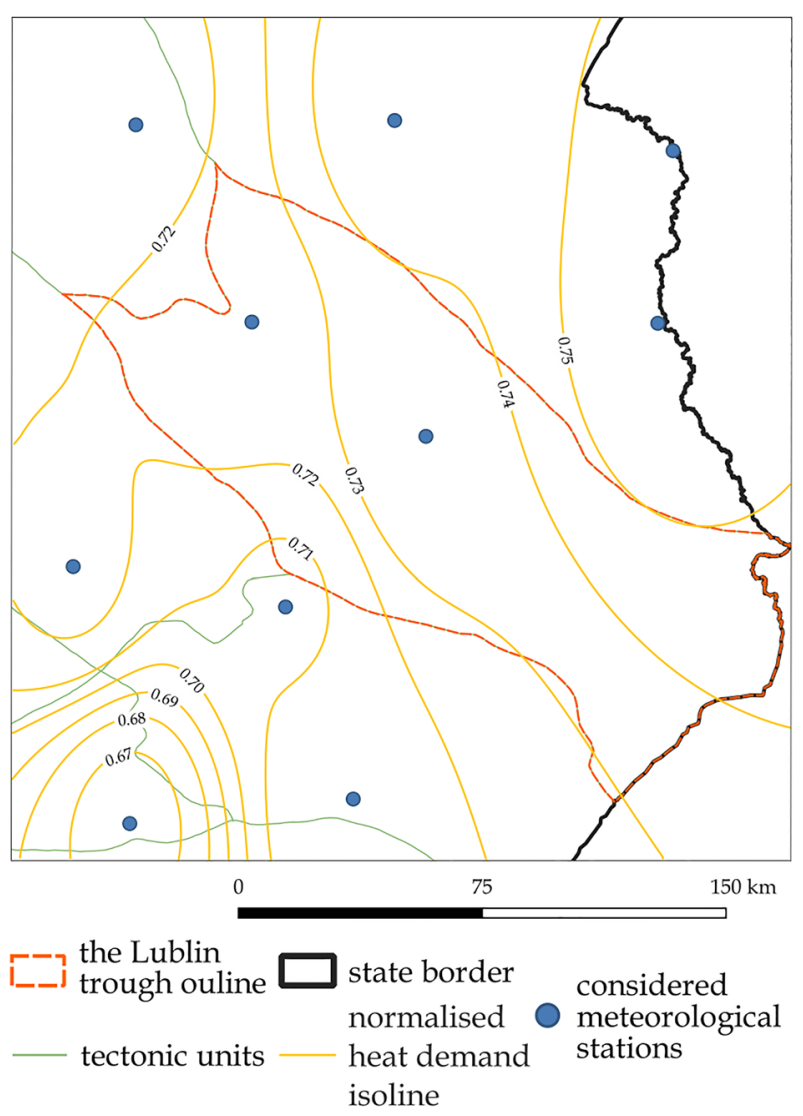

Fig. 6 Normalised heat demand in an exemplary hour. Map presents heat demand in the considered area. Values for a given hour in marked stations (blue dots) were interpolated in GIS software with Inversed Distance Weight (IDW) algorithm with weight parameter set as 3.0. Yellow solid lines mark isolines of normalised heat demand, orange dashed line presents the Lublin trough boundary and green lines represent tectonic units in the map extend within Poland (black solid line)

- In extreme cases, the maximal heat demand may reach $110 \%$ of nominal capacity.

- The lower boundaries of heat demand distribution are related to sanitary hot water preparation, with minimal values of about 0.14 , a 1st percentile of 0.17 and a 25 th percentile of $0.21-0.22$. As heat demand for SHW preparation is clearly related to citizens' habits and preparation mode, these values may vary in real-life conditions.

- The mean (average) value of heat demand is $0.36-0.38$, which is slightly higher than the median (0.33-0.36). Such accordance confirms that the considered population is statistically typical and reflects two roughly equal periods of the year, i.e. the winter season, with heat demand typically reaching $40-60 \%$ of nominal power, and the summer season, with demand of about $20 \%$ of nominal power. These two periods may be observed in the exemplary histograms (Fig. 6) and duration curve (Fig. 7) presented below.

- The upper boundaries are related to space heating in winter. Maximal, absolutely extreme observed values are in the range $99-112 \%$ of nominal power. How extreme these values are may be assessed by comparison with the 99th percentile, which is in the range of $76-82 \%$ of nominal power. The 75 th percentile, which may be consid- 


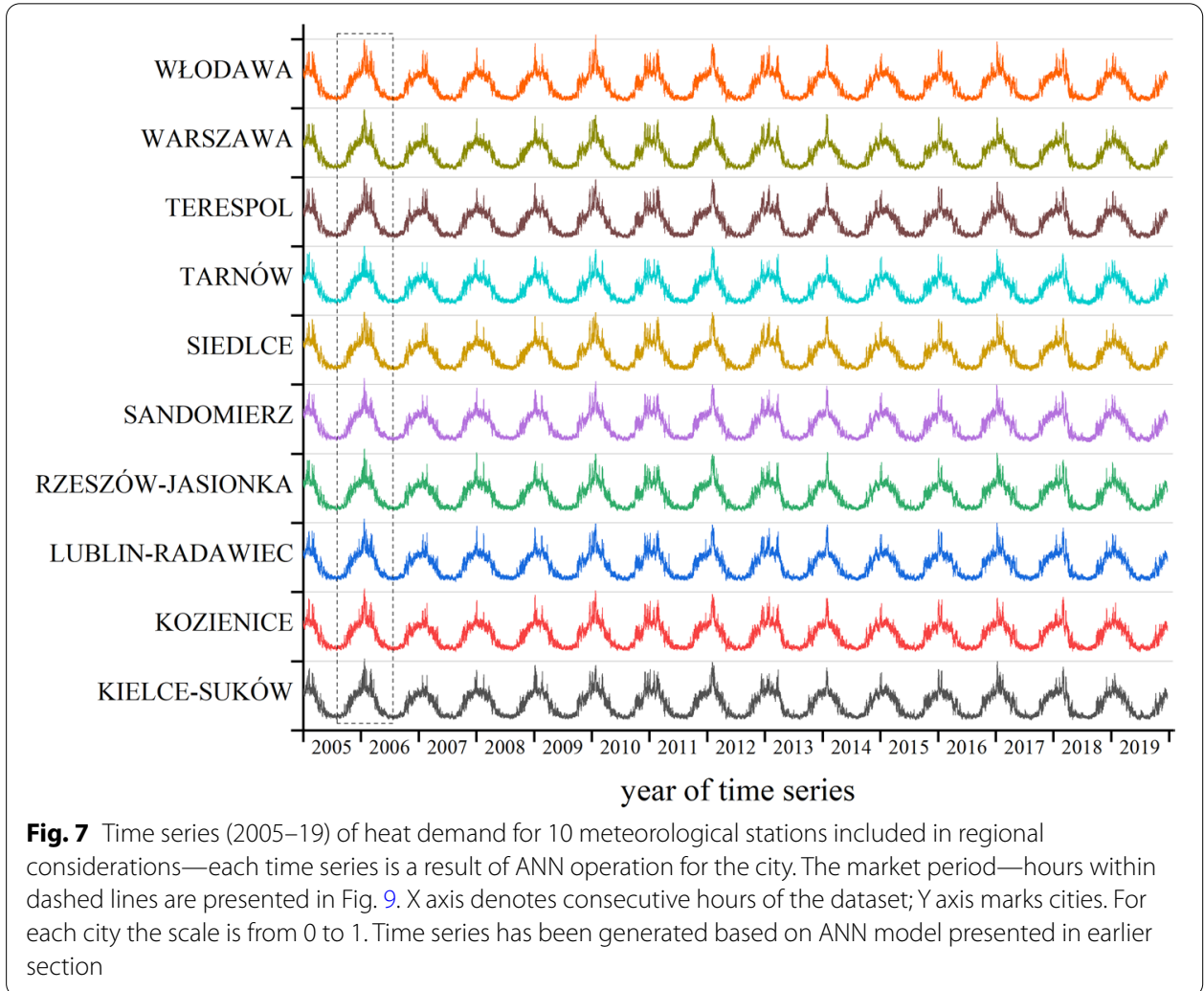

ered the typical value for winter, is in the range of $50-52 \%$ of nominal heat demand. For a regional presentation of median, mean, 75th and 99th percentiles, see Fig. 3.

- The peaks are supposed to be covered by peak source. Sized as described above (see "Input data and methods" section, Eq. 3), the peak heat source should turn on when heat demand exceeds $60-63 \%$ of nominal heat demand (see Fig. 7).

- The geothermal source should be sized accordingly, at $60-63 \%$ of nominal power. Capacity factors obtained with such dimensioning are between 58 and 60\%, which may be considered as beneficial and significantly higher than currently recorded in geoDHs with heat receivers not adjusted to the available resource.

Although the cumulative results are very similar, numbers obtained for a given hour provide insight into dynamic weather conditions throughout the Lublin trough region. An exemplary hour is depicted in Fig. 2. Changes are also visible in time-domain graphs (Figs. 8, 9).

Time series are similar, with some shifts and modifications reflecting the actual conditions regulating local heat demand. Visible shifts and curve flattening (comparing two or more time series) are most likely related to the development of frontal systems.

It is important to note that although winters vary over years, there is a heat volume that may be considered as guaranteed to be sold. These data may be used for preparing economic projections of a future investment's performance. In spite of climate change and visible differences year to year, there is a volume of energy that may be expected 


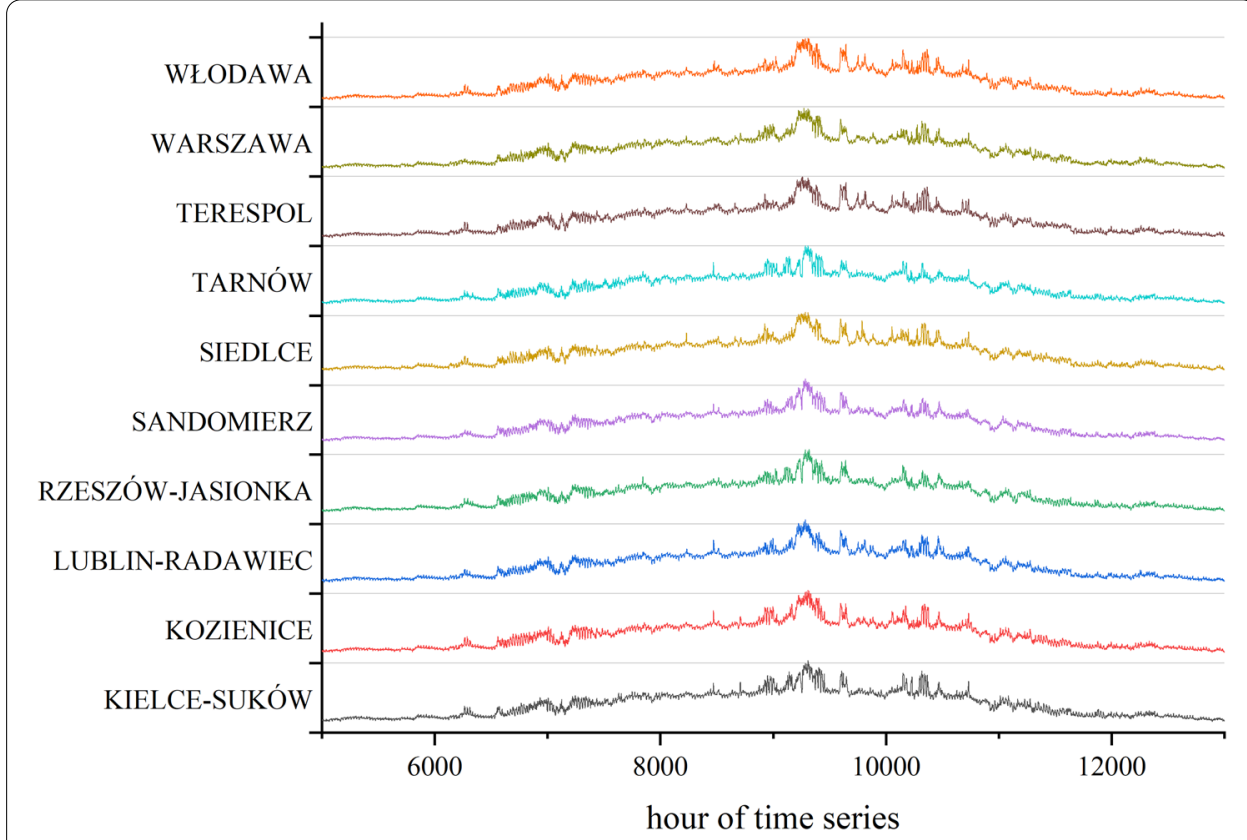

Fig. 8 Time series -winter season 2005/6 (in Fig. 8 marked by dashed lines). Occasional values can be seen to reach $100 \%$ of nominal heat demand or exceed it, and respective demand peaks to mutate from case to case. $X$ axis denotes consecutive hours of the dataset; $Y$ axis marks cities. For each city the scale is from 0 to 1 . Time series has been generated based on ANN model presented in earlier section

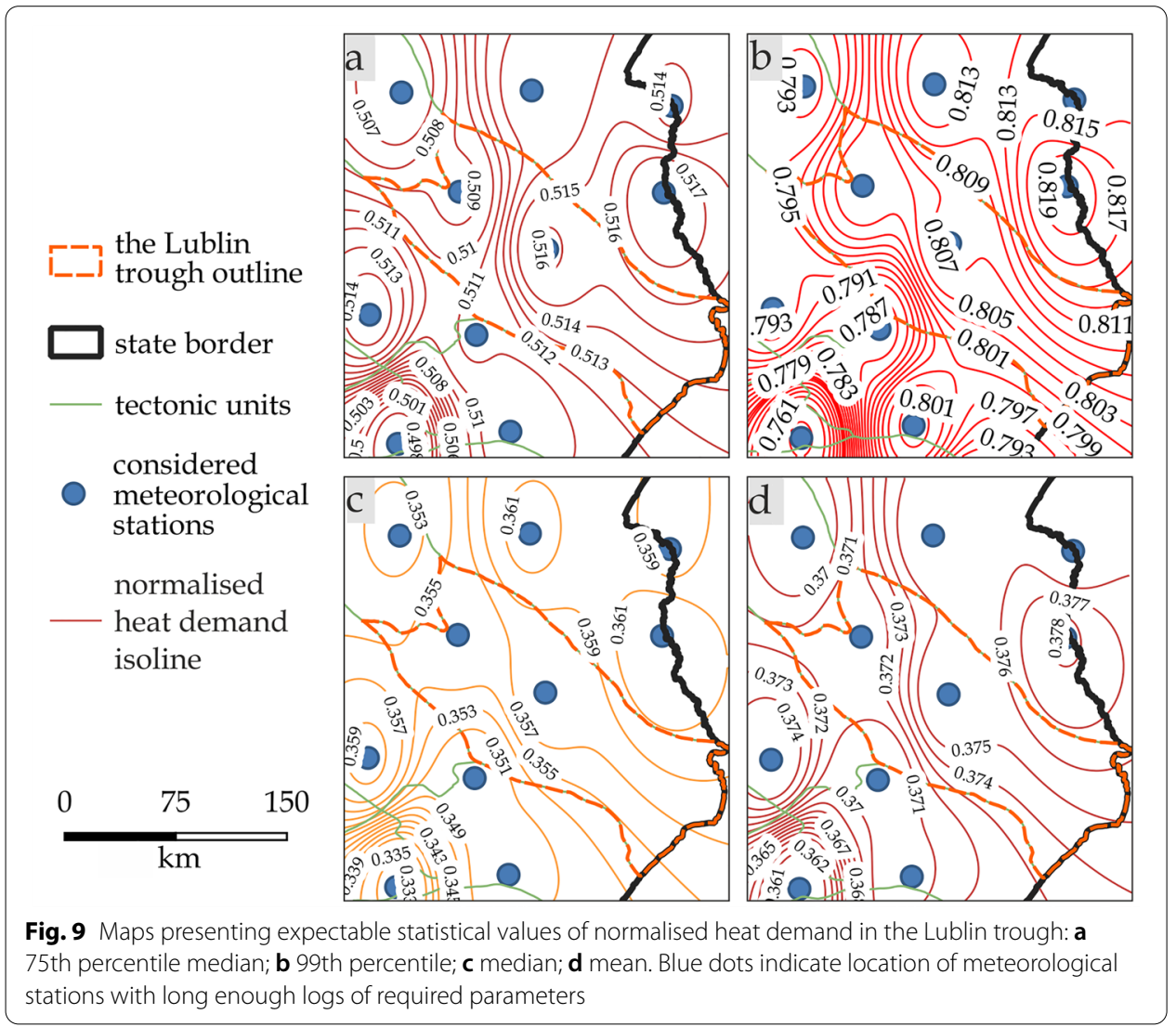




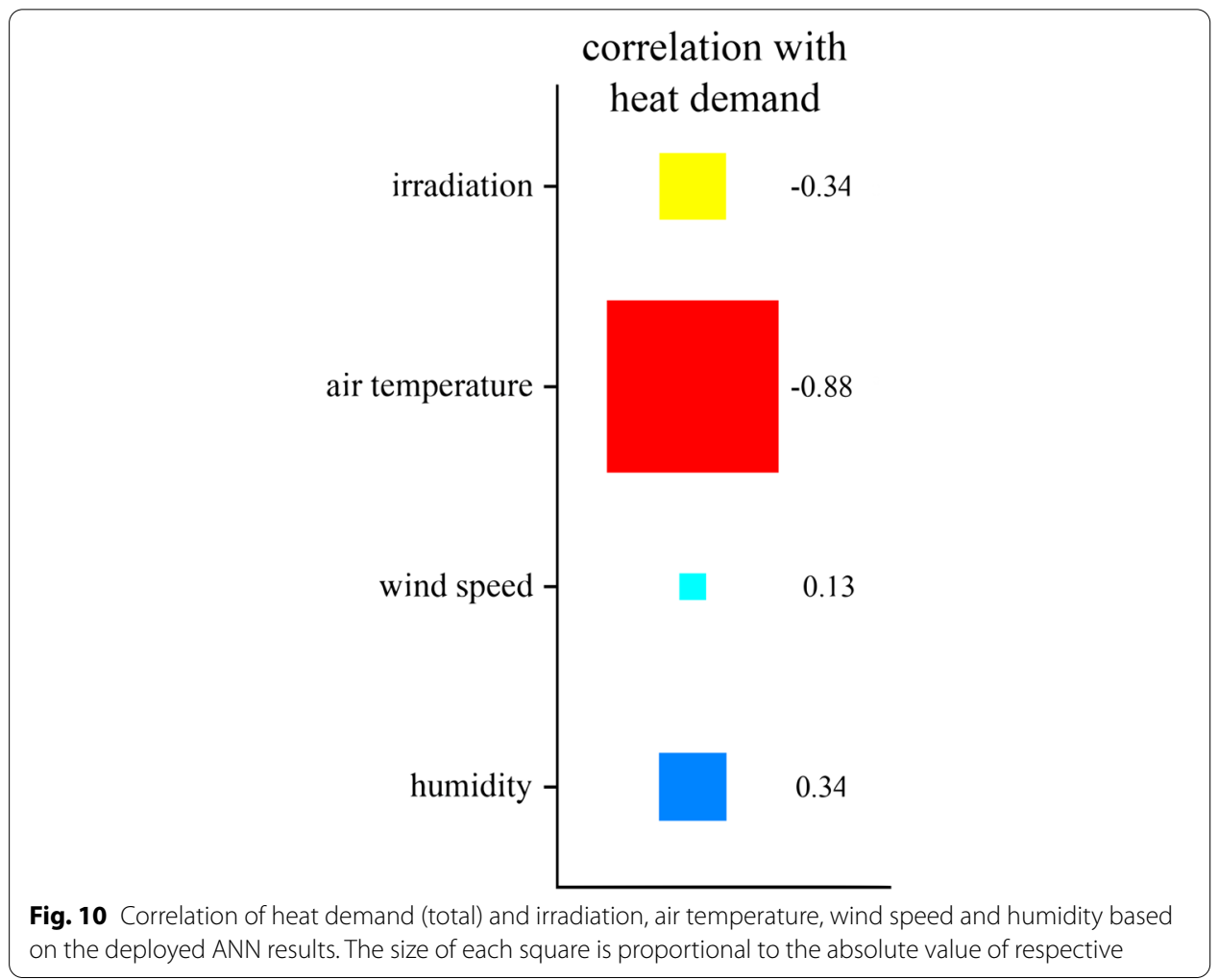

every year-a worst-case scenario. Economical calculations based on worst-case scenarios provide financial stability for the investor and predictable prices for consumers.

In the regional scale for the entire Lublin trough, the following observations may be drawn.

The southernmost part of the region lacks a meteorological station providing reliable and continuous data logs for the considered 15 years, and thus, the results for this part are to be treated as indicative.

The eastern part of the trough is characterised by higher values, which is especially visible in the 75th and 99th percentile map, where differences are twice as high as the ANN error (MAPE). Median and mean values over the trough are generally similar to one another, suggesting both typical heat demand and significantly higher weatherrelated winter peak demands in the eastern part of the region.

Thus, basic load is almost the same over the entire Lublin trough, yet its eastern parts are more demanding in their heat consumption in respect of their peaks of demand. Geographical correlation is not the only observed correlation.

Based on ANN results, the correlation matrix for heat demand and four weather parameters included in the algorithm input was created (Fig. 10). As expected, the most crucial and negatively correlated is external air temperature: solar irradiation also decreases heat demand, but the correlation is not as strong. Surprisingly, the effect of wind on increasing heat load is limited. Humidity seems to influence heat demand, which may be explained by citizen's comfort temperature rising with humidity, or by humidity resulting from other mentioned weather parameters. 


\section{Conclusions}

Despite possible errors induced by ANN and input defects, there are many conclusions that may be drawn. The most general one is that climatological conditions facilitate the use of geothermal energy in the Lublin trough. The consecutive years considered in this paper, though variable, remained similar, which means it is comparatively easy to assume safe values of maximal heat demand and energy sold. Such a situation is beneficial for the investors and managers of a geothermal heat source, as it provides the opportunity to reliably assess expected incomes and the risk of their being reduced in any given year.

Median values tend generally to be less than zero, which means that increases in heat demand tend to be slightly more rapid than do decreases, yet the difference is very slight and should be studied in detail in the future.

Capacity factors are in a favourable range, assuming the receiver's compatibility with the heat source's thermal parameters. Although it is a very optimistic assumption for existing buildings, there is a well-reasoned expectation that new buildings using floor heating and internal heat pumps should lower the expected temperature parameters of district heating in the future. The offered capacity factors also justify reducing expectations regarding heat supply.

Ramp rates observed in the presented model show significant variability, so seem to be low enough to allow for safe geothermal heat plant operation in most hours over the studied period. Although it remains unknown what ramp rate value would cause adverse solid particles to be raised in a specific case, it has been determined what the most expected value is and the maximum possibly recorded value for which pumping tests should be performed. Although it is not common to assess maximum safe pumping ramp rates for geothermal wells at the level of well testing, it should become standard in order to avoid the need for tests to be conducted during operation, as these may be harmful to the installed operational equipment.

Reservoir tests should include a pumping rate change corresponding to a change of $\pm 20 \mathrm{~kW}_{\mathrm{t}}$ per $1000 \mathrm{~kW}_{\mathrm{t}}$ of nominal output per hour; testing for a $\pm 200 \mathrm{kWt}$ pumping rate change should cover all expectable events during typical operation in a long time period. As ramp rates reaching up to $\pm 20 \%$ of nominal heat demand may well be harmful to the geothermal well and the equipment, such risk should be tackled by proper management and heat storage, which might additionally increase the well's capacity factor alongside reducing peak source use. Fortunately, such high ramp rates are observed only rarely, and threats should be assessed during reservoir tests.

This ramp rate gives clues regarding peak source capacity modulation and preferred modularity. For the assumed criteria of peak source dimensioning, its capacity is of about $40 \%$ of nominal power, yet it is extremely unlikely that within one hour the change in demand will be more than $20 \%$ of nominal power. Thus, there is a significant benefit in using at least two peak sources $(2 \times 0.2)$. Such an approach may increase the system's efficiency and reliability.

Peak heat demand is at level of about $5000-6000 \mathrm{~h}$ over 15 years (less than $5 \%$ of total time) or, in other words, a total of one heating season over the analysed 15 years. This is a non-ignorable number of instances for which peak source should be provided, yet it may be expected that smart district heating, including demand-side management 
and energy storage, may provide a significant decrease in the number and amplitude of observed peaks. This would further facilitate the use of a geothermal heat source.

The general conclusion may also be drawn that Polish norms regulating designed heat load may need some corrections, as they are probably too demanding, making it a notso-risky yet lucrative practice not to follow them, especially in detached houses. Additionally, the observed sequences in peaks suggest that heat demand observed in nearby cities may give valuable input data for controlling district heating, as weather forecasts do not include customers' habits or spontaneous circumstances (holidays, etc.).

Regarding the investment reality, climate factors in the Lublin trough affect heat demand in a way that facilitates the development of district heating, especially geothermal district heating, because of the stability and predictability of heat consumption. The results of this paper indicate that the climate in south-eastern Poland provides that low-temperature geothermal resources available in the Lublin trough may be effectively exploited.

\section{Future work and acknowledgements}

In future, more detailed studies may be performed with separate datasets for various types of heat consumers. It is also important to determine in detail available geothermal water resources-their abundance and temperature-as this would indicate which sizes of geothermal heat consumers should be studied in future in this region.

The work is part of the $\mathrm{PhD}$ thesis of Bartłomiej Ciapała. This research was funded by the statutory research programme at the Faculty of Geology, Geophysics and Environmental Protection AGH University of Science and Technology in Kraków, Poland, statutory work No. 16.16.140.315.

\section{Appendix 1}

\section{See Fig. 11.}

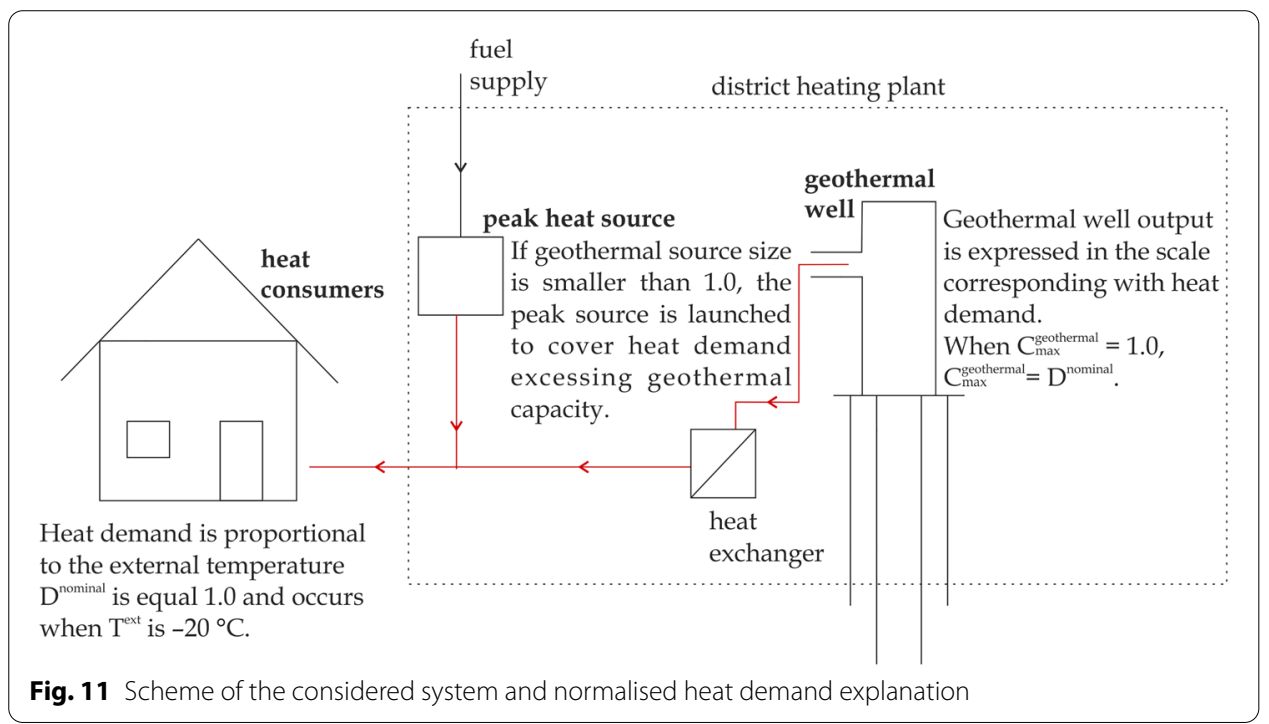




\section{Supplementary Information}

The online version contains supplementary material available at https://doi.org/10.1186/s40517-021-00184-1.

Additional file 1. Time laps of expected heat demand changes over years 2005-2007.

\section{Acknowledgements}

Not applicable.

\section{Authors' contributions}

$\mathrm{BC}$ contributed to research design, data preparation, text writing and result analyses; JJ was involved in data processing and evaluation, result analyses and text writing; $\mathrm{MJ}$ and BK performed research design, results consultation and text writing.

\section{Funding}

All funding sources were declared.

\section{Availability of data and materials}

Data used for present considerations were obtained from open sources mentioned in the text; since the data do not belong to Authors nor their institution, the datasets are available at their owner's websites: https://danepubliczne.imgw. $\mathrm{pl}$ /, http://www.soda-pro.com/zh/web-services/radiation/cams-radiation-service. The dataset used in ANN preparation process is confidential data belonging to Geotermia Mazowiecka S.A. and has been exclusively shared upon official request.

\section{Competing interests}

The authors declare neither competing interests nor conflict of interest.

\section{Author details}

${ }^{1}$ AGH University of Science and Technology, Kraków, Poland. ${ }^{2}$ School of Business, Society and Engineering, Mälardalens Högskola, 72113 Västerås, Sweden. ${ }^{3}$ Faculty of Environmental Engineering, Wroclaw University of Science and Technology, 50-370 Wroclaw, Poland. ${ }^{4}$ Instytut Gospodarki Surowcami Mineralnymi I Energią PAN, Kraków, Poland.

Received: 4 November 2020 Accepted: 6 January 2021

Published online: 08 February 2021

\section{References}

Beale H, Demuth H, Pws MH-, Boston U, 1996 U. Neural network design. pdfs.semanticscholar.org [Internet]. 1995 [cited 2020 Jun 13]; https://pdfs.semanticscholar.org/6a81/22861b80842ee6f406acdeec35aec913f1b8.pdf.

Canales FA, Jadwiszczak P, Jurasz J, Wdowikowski M, Ciapała B, Kaźmierczak B. The impact of long-term changes in air temperature on renewable energy in Poland. Sci Total Environ. 2020;10(729):138965.

Chicherin S. Methodology for analyzing operation data for optimum district heating (DH) system design: ten-year data of Omsk, Russia. Energy [Internet]. 2020 Aug 18 [cited 2020 Aug 20];118603. https://linkinghub.elsevier. com/retrieve/pii/S0360544220317114.

Ciapała B, Jurasz J, Kies A. The potential of wind power-supported geothermal district heating systems-model results for a location in Warsaw (Poland). Energies. 2019;12(3706):1-16.

Guelpa E, Marincioni L, Verda V. Towards 4th generation district heating: prediction of building thermal load for optimal management. Energy. 2019;15(171):510-22.

Gustafsson SI. Climate influence on district heating and electricity demands. Appl Energy. 1992;42(4):313-20.

Jurasz J, Ciapała B. Solar-hydro hybrid power station as a way to smooth power output and increase water retention. Sol Energy [Internet]. 2018 Oct 1 [cited 2019 Mar 14];173:675-90. https://www.sciencedirect.com/science/artic le/pii/S0038092X18307527.

Kępińska B. Geothermal energy use, country update for Poland Beata Kę pi ń ska. Strasbourg: European geothermal congress; 2016. pp 1-10.

Kies A, Schyska B, von Bremen L, Kies A, Schyska BU, von Bremen L. Curtailment in a Highly Renewable Power System and Its Effect on Capacity Factors. Energies [Internet]. 2016 Jun 30 [cited 2019 Jan 4]; 9(7):510. http://www.mdpi.com/ 1996-1073/9/7/510.

Kozarcanin S, Liu H, Andresen GB. 21st Century climate change impacts on key properties of a large-scale renewablebased electricity system. Joule. 2019;3(4):992-1005.

Kryzia D, Kuta M, Matuszewska D, Olczak P. Analysis of the Potential for Gas Micro-Cogeneration Development in Poland Using the Monte Carlo Method. Energies [Internet]. 2020 Jun 17 [cited 2020 Aug 13];13(12):3140. https://www.mdpi. com/1996-1073/13/12/3140.

Kunze C, Hertel M. Contested deep geothermal energy in Germany - the emergence of an environmental protest movement, Energy Research and Social Science, vol. 27. Amsterdam: Elsevier; 2017. p. 174-80.

Li W, Liu X, Jiang X. Review on the study on migration and deposition of particles in porous media. Trans Geotherm Resour Counc. 2017:41:1680-8.

Lund JW, Lienau PJ. Geothermal district heating. In: International Summer School Session 2: Geothermal district heating projects: technical and eco-nomic feasibility for organization in central European conditions II1 geothermal district heating [Internet]. 2009; 1-18. https://pangea.stanford.edu/ERE/pdf/IGAstandard/ISS/2009Slovakia/II.1.LUND.pdf. 
Matuszewska D, Kuta M, Olczak P. Techno-economic assessment of mobilized thermal energy storage system using geothermal source in polish conditions. Energies [Internet]. 2020 Jul 2 [cited 2020 Aug 13]; 13(13):3404. https://www. mdpi.com/1996-1073/13/13/3404.

Mines, Greg, Nathwani J, Richard C, Hanson H, Wood R. Geothermal plant capacity factors. In: Stanford geothermal workshop, Palo Alto, CA (United States), 26-28 Jan 2015 [Internet]. 2015. https://www.osti.gov/biblio/1178377.

Mosavi A, Salimi M, Ardabili SF, RabczukT, Shamshirband S, Varkonyi-Koczy AR. State of the art of machine learning models in energy systems, a systematic review. mdpi.com [Internet]. 2019 [cited 2020 Jun 13];12. www.mdpi.com/ journal/energies.

Mukhopadhyay S. Deep learning and neural networks. Advanced data analytics using python. Berkeley, CA: Apress; 2018. pp 99-119.

Østergaard D, Svendsen S. Space heating with ultra-low-temperature district heatinga case study of four single-family houses from the1980s. In: Energy procedia. Amsterdam: Elsevier; 2017s. p. 226-35.

Pellizzone A, Allansdottir A, De Franco R, Muttoni G, Manzella A. Assessment of social acceptance of geothermal energy exploitation in southern Italy. Eur Geotherm Congr. 2013;1-6.

Pożaryski W. Podział obszaru Polski na jednostki tektoniczne. In: Pożaryski W (ed.), Budowa geologiczna Polski, vol. 4, Tektonika part 1 Niż Polski. Wydawnictwa. Warszawa: Geologiczne; 1974. pp 24-34

Schüppler S, Fleuchaus P, Blum P. Techno-economic and environmental analysis of an Aquifer Thermal Energy Storage (ATES) in Germany. Geotherm Energy. 2019. https://doi.org/10.1186/s40517-019-0127-6.

Sheela KG, Deepa SN. Review on methods to fix number of hidden neurons in neural networks. Math Probl Eng [Internet]. 2013;2013:1-11. http://www.hindawi.com/journals/mpe/2013/425740/.

Song J, Xue G, Pan X, Ma Y, Li H. Hourly heat load prediction model based on temporal convolutional neural network. IEEE Access [Internet]. 2020 [cited 2020 Jun 13];8:16726-41. https://ieeexplore.ieee.org/abstract/document/89643 99/.

Tissen C, Menberg K, Bayer P, Blum P. Meeting the demand: geothermal heat supply rates for an urban quarter in Germany. Geotherm Energy. 2019. https://doi.org/10.1186/s40517-019-0125-8.

Tobin I, Jerez S, Vautard R, Thais F, Van Meijgaard E, Prein A, et al. Climate change impacts on the power generation potential of a European mid-century wind farms scenario. Environ Res Lett 2016;11(3):034013.

Vargas PS. Understanding social acceptance of geothermal energy: case study for Araucanía region. Chile Geothermics. 2018;1(72):138-44.

Volkova A, Krupenski I, Pieper H, Ledvanov A, Latôšov E, Siirde A. Small low-temperature district heating network development prospects. Energy. 2019;1(178):714-22.

Weber J, Ganz B, Sanner B, Moeck I. Geothermal energy use, country update for Germany. Strasbourg: European geothermal congress; 2016. pp 19-24.

Yabanova I, Keçebaş A. Development of ANN model for geothermal district heating system and a novel PID-based control strategy. Appl Therm Eng. 2013;51(1-2):908-16.

\section{Publisher's Note}

Springer Nature remains neutral with regard to jurisdictional claims in published maps and institutional affiliations.

\section{Submit your manuscript to a SpringerOpen ${ }^{\circ}$ journal and benefit from:}

- Convenient online submission

- Rigorous peer review

- Open access: articles freely available online

- High visibility within the field

- Retaining the copyright to your article

Submit your next manuscript at $\boldsymbol{\nabla}$ springeropen.com 